\title{
ASSESSMENT OF CURRENT SITUATION AND VARIATION OF WET RICE LAND CULTIVATION AREA IN THE RED RIVER DELTA REGION
}

\author{
Vu Thi Thu Huong ${ }^{1,2}$, Cao Viet $\mathrm{Ha}^{3}$, Ngo Van Gioi ${ }^{*}$ \\ ${ }^{1}$ Graduate University of Science and Technology - VAST, ${ }^{2}$ Institute of Geography - VAST \\ ${ }^{3}$ Vietnam National University of Agriculture, ${ }^{4}$ TNU - University of Sciences
}

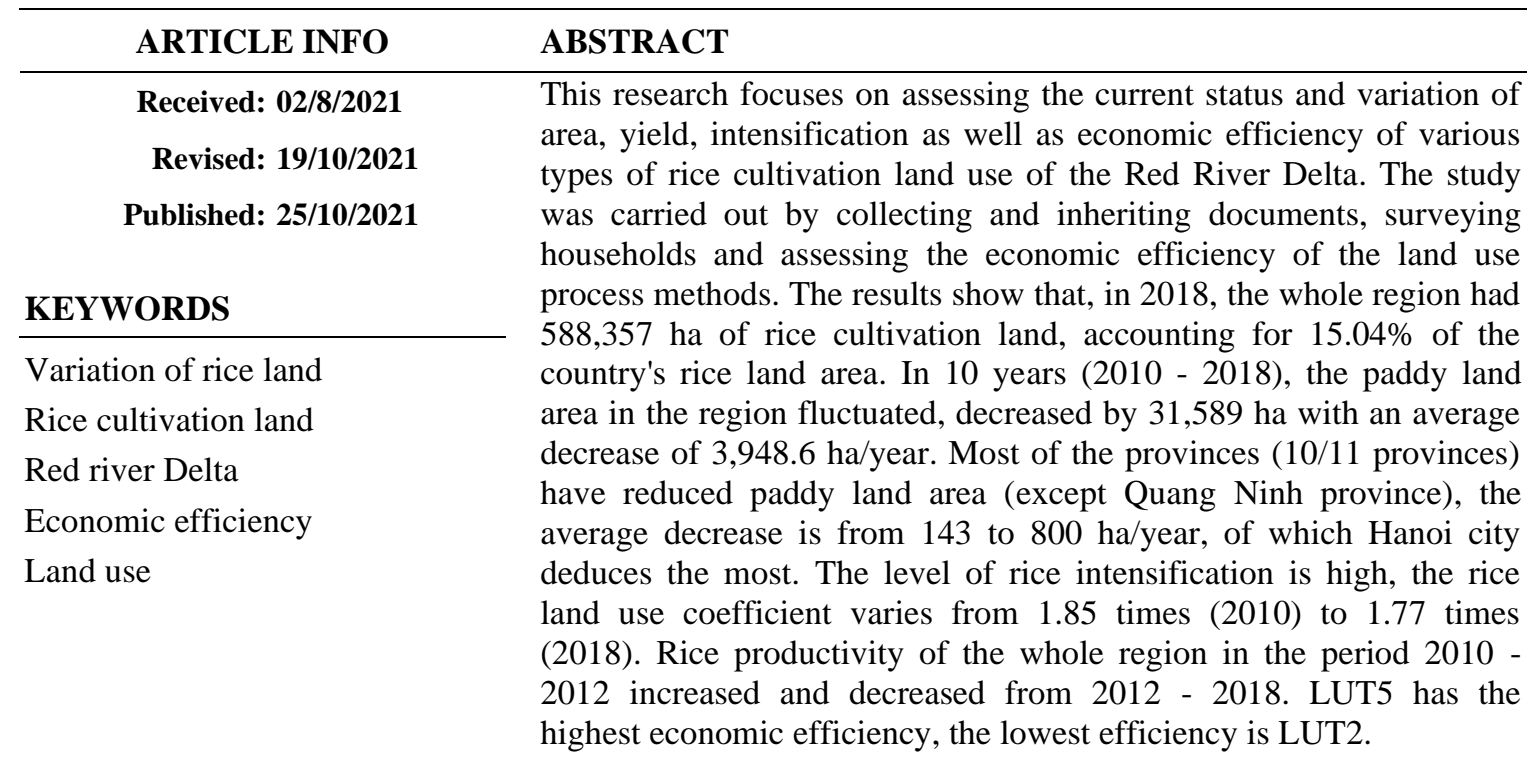

\section{ĐÁNH GIÁ HIỆN TRẠNG VÀ BIẾN ĐỘNG DIỆN TÍCH ĐẤT TRỔNG LÚA NƯỚC VÙNG ĐỒNG BẰNG SÔNG HỒNG}

\author{
Vũ Thị Thu Hường ${ }^{1,2}$, Cao Việt Hà ${ }^{3}$, Ngô Văn Giới ${ }^{4 *}$ \\ ${ }^{1}$ Học Viện Khoa học và Công nghệ - Viện Hàn lâm Khoa học và Công nghệ Việt Nam \\ ${ }^{2}$ Viện Địa lý - Viện Hàn lâm Khoa học và Công nghệ Việt Nam \\ ${ }^{3}$ Học viện Nông nghiệp Việt Nam, ${ }^{4}$ Truờng Đại học Khoa học - ĐH Thái Nguyên
}

\begin{tabular}{|c|c|}
\hline THÔNG TIN BÀI BÁO & TÓM TẮT \\
\hline Ngày nhận bài: 02/8/2021 & \multirow{10}{*}{ 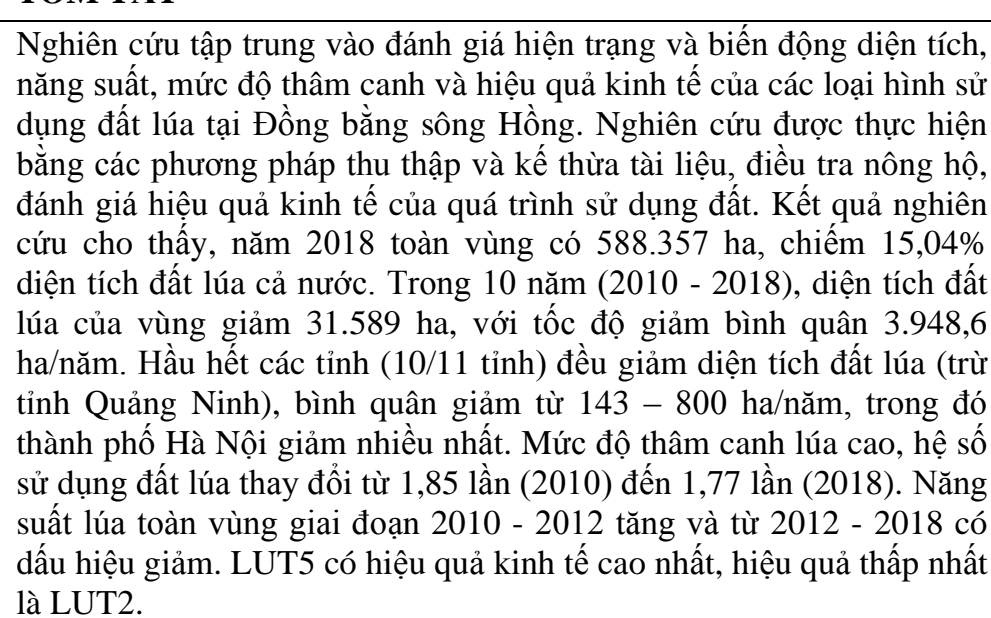 } \\
\hline Ngày hoàn thiện: 19/10/2021 & \\
\hline Ngày đăng: 25/10/2021 & \\
\hline TÙ KHÓA & \\
\hline Biến động đất lúa & \\
\hline Đất trồng lúa & \\
\hline Đồng bằng sông Hồng & \\
\hline & \\
\hline & \\
\hline & \\
\hline
\end{tabular}

DOI: https://doi.org/10.34238/tnu-jst.4824

\footnotetext{
${ }^{*}$ Corresponding author. Email: gioinv@tnus.edu.vn
} 


\section{Giới thiệu}

Theo báo cáo của Tổng cục Thống kê năm 2020, diện tích gieo trồng lúa thu đông ước đạt 724 nghìn ha, giảm 0,2 nghìn ha so với cùng kỳ năm trước. Diện tích gieo cấy lúa mùa cả nước (1.584,6 nghìn ha) giảm 27 nghìn ha so với vụ mùa năm 2019 [1]. Đồng bằng sông Hồng (ĐBSH) là vùng trọng điểm sản xuất lúa đứng thứ 3 của cả nước sau vùng Đồng bằng sông Cửu Long (ĐBSCL), vùng Bắc Trung Bộ và Duyên hải miền Trung. Năm 2018, tổng sản lượng lúa của vùng là 6.292 .400 tấn chiếm $14,3 \%$ tổng sản lượng lúa quốc gia, góp phần đảm bảo an ninh lương thực trong vùng [2]. Theo FAO, diện tích đất nông nghiệp của Việt Nam chiếm khoảng $35 \%$ tổng diện tích của cả nước và tạo ra khoảng $47 \%$ việc làm. Tuy vậy, các nghiên cứu gần đây cho thấy diện tích đất nông nghiệp nói chung và lúa nước nói riêng có sự biến động đáng kể theo các kịch bản của biến đổi khí hậu, nước biển dâng. Theo đánh giá của Ngân hàng Phát triển châu $A$ A $(\mathrm{ADB})$, nếu nhiệt độ bình quân tăng lên $1^{\circ} \mathrm{C}$ thì năng suất lúa sẽ giảm $10 \%$ và điều này vô cùng quan trọng với những quốc gia bị ảnh hưởng nghiêm trọng bởi biến đổi khí hậu như Việt Nam [3]. Theo Viện Khoa học Khí tượng thủy văn và Biến đổi khí hậu, nếu nước biển dâng $1 \mathrm{~m}$, vùng Đồng bằng sông Hồng bị ngập 16,8\% diện tích [3], [4]. Các kịch bản khác cũng cho thấy, tới năm 2030, khi nước biển dâng $17 \mathrm{~cm}$ thì diện tích lúa ĐBSCL bị ngập 15.152 ha [5]. Các nghiên cứu về khu vực Đông Nam Á cho thấy rằng, biến đổi khí hậu có thể làm giảm sản lượng nông nghiệp từ 15 - 26\% ở Thái Lan, 2 - 15\% ở Việt Nam, 12 - 23\% ở Philippines và 6 - 18\% ở Indonesia [6]. Ngoài nguyên nhân đất nông nghiệp có thể sẽ bị giảm do biến đổi khí hậu và nước biển dâng các nghiên cứu khác như nghiên cứu của Lưu Thế Anh và cộng sự cho thấy giai đoạn 1995-2015 quỹ đất nông nghiệp đã giảm đáng kể do mở rộng quỹ đất xây dựng và đô thị [7]. Theo báo cáo của Ngân hàng thế giới (2016), Việt Nam có yếu tô năng suất từng tăng trưởng mạnh nhưng tốc độ tăng trưởng đã giảm xuống trong những năm gần đây [8]. Xuất phát từ những lý do trên, việc đánh giá hiện trạng và biến động sử dụng đất trồng lúa vùng ĐBSH là cần thiết, kết quả nghiên cứu sẽ là căn cứ để đề xuất hướng sử dụng đất lúa hợp lý trong tương lai.

\section{2. Đối tượng và phương pháp nghiên cứu}

\section{1. Đối tự̆ng nghiên cúu}

- Đối tượng nghiên cứu: Đất trồng lúa nước và các loại hình sử dụng đất lúa (Quy định theo Luật đất đai 2013). Nghiên cứu được thực hiện với toàn bộ đất trồng lúa nước vùng ĐBSH, bao gồm 11 tỉnh, thành phố: Hà Nội, Hải Phòng, Vĩnh Phúc, Hà Nam, Ninh Bình, Nam Định, Thái Bình, Hưng Yên, Hải Dương, Bắc Ninh, Quảng Ninh.

- Đối tượng đánh giá hiệu quả kinh tế các loại sử dụng đất trồng lúa tại 5 tỉnh/thành phố: Hà Nội, Ninh Bình, Thái Bình, Hải Dương và Nam Định. Với 4 loại sử dụng đất lúa là LUT1: 2 vụ lúa (đất vàm thấp), LUT2: 2 vụ lúa - 1 vụ rau màu (đất vàm thường), LUT3: 1 lúa - 2 vụ rau màu (đất khu vực cao), LUT4: 1 vụ lúa - 1 vụ nuôi trồng thủy sản (đất thấp trũng), vùng Tứ Kỳ, tỉnh Hải Dương LUT5: Lúa - Rươi.

\subsection{Phương pháp nghiên cứu}

- Phưong pháp thu thập, kế thìa tài liệu, số liệu: Các số liệu về hiện trạng sử dụng đất, tình hình sản xuất lúa ở vùng ĐBSH được thu thập, kế thừa từ các cơ quan chức năng như Bộ Tài nguyên môi trường (TNMT), Bộ Nông nghiệp và Phát triển nông thôn (NN\&PTNT), Tổng cục thống kê...

- Phurong pháp điều tra nông hộ: Sử dụng phương pháp điều tra nhanh nông thôn có sự tham gia của người dân bằng phiếu tại 5 tỉnh/thành phố là Hà Nội, Ninh Bình, Thái Bình, Hải Dương và Nam Định. Mỗi tỉnh điều tra 70 hộ nông nghiệp ở một huyện thuần nông. Tổng số đã điều tra 350 hộ.

- Phương pháp đánh giá hiệu quả kinh tế sử dụng đất: Sử dụng các chỉ số được tính theo các công thức sau: 
- Giá trị sản xuất (GTSX):

$$
\text { GTSX }=\sum\left[(\text { giá nông sản })_{\mathrm{i}} \mathrm{X}(\text { năng suất })_{\mathrm{i}}\right]
$$

- Chi phí trung gian (CPTG): Là tổng các chi phí vật chất (giống, phân bón, thuốc bảo vệ thực vật, thuê làm đất, tuốt lúa, khấu hao dụng cụ,...)

- Thu nhập hỗn hợp (TNHH):

- Giá trị ngày công (GTNC)

$$
\text { TNHH }=\text { GTSX }- \text { CPTG }
$$

- Hiệu quả đồng vốn (HQĐV):

$$
\text { GTNC = TNHH/số công lao động }
$$

$$
\mathrm{HQĐV}=\mathrm{TNHH} / \mathrm{CPTG}
$$

\section{Kết quả nghiên cứu và thảo luận}

\subsection{Tài nguyên đất trồng lúa của vùng Đồng bằng sông Hồng}

Vùng ĐBSH là vùng đồng bằng lớn thứ hai của Việt Nam sau ĐBSCL. Vùng ĐBSH theo quy định của Bộ NN\&PTNT bao gồm địa bàn của 11 tỉnh Hà Nội, Hải Phòng, Vĩnh Phúc, Hà Nam, Ninh Bình, Nam Định, Thái Bình, Hưng Yên, Hải Dương, Bắc Ninh, Quảng Ninh. Theo số liệu thống kê của Viện Quy hoạch và thiết kế Nông nghiệp ĐBSH có tổng diện tích tự nhiên là 1.485.100 ha bao gồm 11 nhóm đất, diện tích từng nhóm được thống kê trong bảng 1 [9].

Bảng 1. Tài nguyên đất của vùng Đồng bằng sông Hồng

\begin{tabular}{llccc|}
\hline TT & \multicolumn{1}{c}{ Tên đất } & Ký hiệu & Diện tích (1.000 ha) & Tỷ lệ (\%) \\
\hline 1 & Bãi cát, cồn cát và đất cát biển & $\mathrm{C}$ & 12,1 & 0,81 \\
2 & Đất mặn & $\mathrm{M}$ & 112,4 & 7,57 \\
3 & Đất phèn & $\mathrm{S}$ & 75,6 & 5,09 \\
4 & Đất phù sa & $\mathrm{P}$ & 919,8 & 61,94 \\
5 & Đất lầy và than bùn & $\mathrm{J} \& \mathrm{~T}$ & 1,0 & 0,07 \\
6 & Đất xám và xám bạc màu & $\mathrm{X} \& \mathrm{~B}$ & 68,6 & 4,62 \\
7 & Đất đỏ vàng & $\mathrm{F}$ & 158,9 & 10,70 \\
8 & Đất mùn vàng đỏ trên núi & $\mathrm{H}$ & 4,1 & 0,28 \\
9 & Đất thung lũng & $\mathrm{D}$ & 3,6 & 0,24 \\
10 & Đất xói mòn trơ sỏi đá & $\mathrm{E}$ & 0,4 & 0,03 \\
& Tô̂ng diện tích đất & & $1.358,8$ & 1,50 \\
& Tổng diện tích tự nhiên (gồm cả sông suối, núi đá) & & $1.485,1$ & 100,00 \\
\hline \multicolumn{2}{r}{ (Nguồn: Bộ Nông nghiệp và Phát triển Nông thôn, 2009) }
\end{tabular}

Trong 11 nhóm đất của ĐBSH, lúa nước được trồng chủ yếu trong các nhóm đất: Đất phù sa, đất mặn, đất phèn, đất đỏ vàng biến đổi do trồng lúa nước. Các nhóm đất lầy, đất cát và đất xám bạc màu cũng có trồng lúa nước nhưng diện tích nhỏ. Theo thống kê của Bộ Tài Nguyên và Môi Trường năm 2018 trong 6 vùng địa lý, tự nhiên - kinh tế toàn quốc, diện tích đất lúa của ĐBSH đứng thứ 3 chiếm 588.357 ha, tỷ lệ diện tích đất lúa tại các vùng được thể hiện tại hình 1 [10].

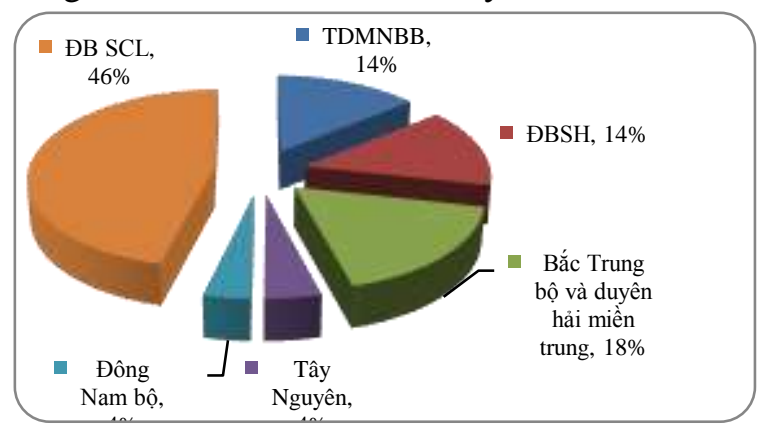

Hình 1. Diện tích đất lúa ở các vùng địa lý, tụ nhiên - kinh tế tính đến ngày 31/12/2018

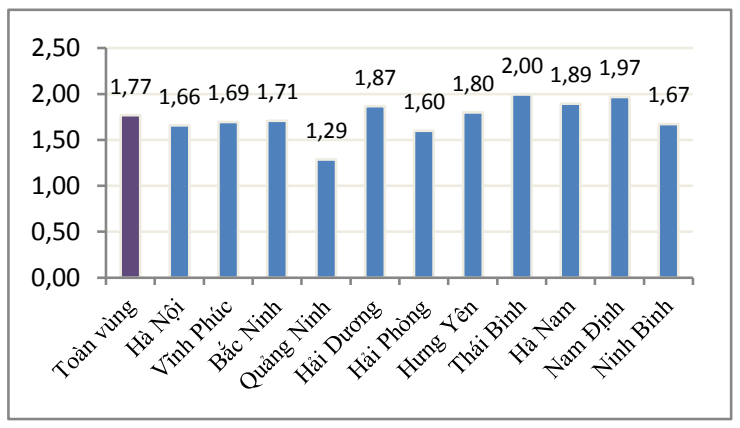

Hình 2. Hệ số sủ dụng đất lúa ở vùng Đồng bằng sông Hồng năm 2018 


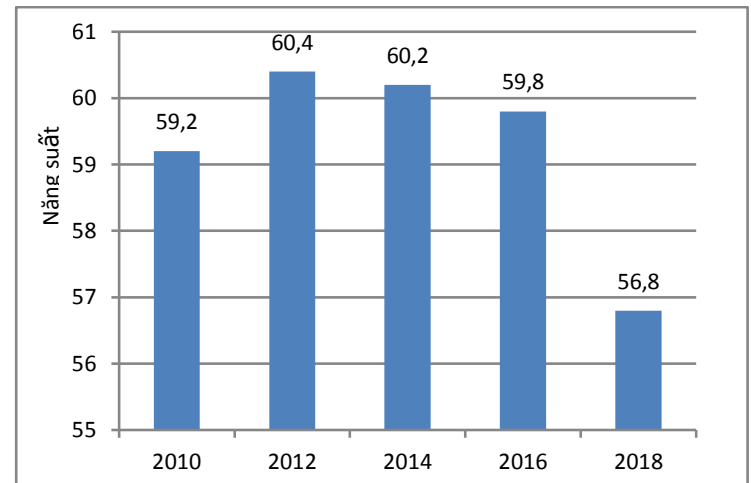

Hình 3. Biến động năng suất lúa cả năm của vùng Đồng bằng sông Hồng giai đoạn 2010-2018

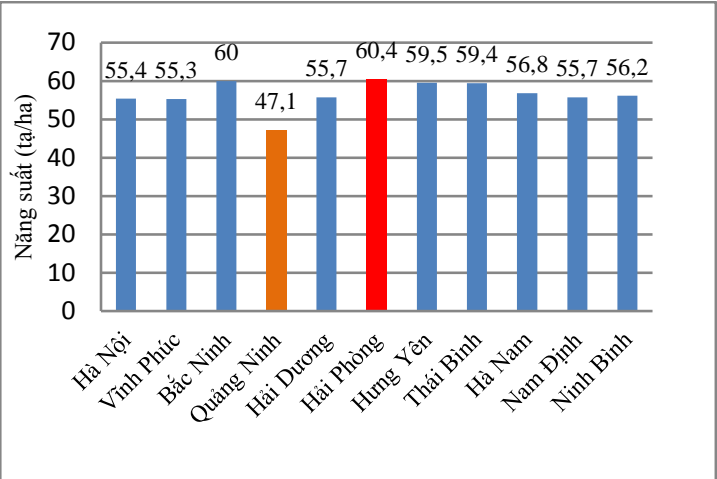

Hình 4. Năng suất lúa trung bình cả năm của các tỉnh vùng Đồng bằng sông Hồng năm 2018

\subsection{Sử dụng đất trồng lúa vùng Đồng bằng sông Hồng giai đọ̣n 2010-2018}

\subsubsection{Biến động diện tích đất trồng lúa ở vùng Đồng bằng sông Hồng giai đoạn 2010-2018}

Theo số liệu công bố của Bộ Tài nguyên và Môi trường, từ năm 2010, diện tích đất lúa vùng ĐBSH trung bình năm liên tục giảm, do chuyển mục đích sử dụng sang đất phi nông nghiệp. Biến động sử dụng đất lúa giai đoạn 2010 - 2018 của toàn vùng ĐBSH và của từng tỉnh được thể hiện tại bảng 2 [2].

Bảng 2. Biến động diện tích đất trồng lúa ở vùng Đồng bằng sông Hồng giai đoạn 2010-2018 (ha)

\begin{tabular}{clcccc}
\hline \multirow{2}{*}{ TT } & \multirow{2}{*}{ Đơn vị hành chính } & \multicolumn{2}{c}{ Diện tích đất lúa } & \multirow{2}{*}{ Biến động diện tích } & $\begin{array}{c}\text { Diện tích tăng (+), } \\
\text { giảm (-) TB/ năm }\end{array}$ \\
\cline { 3 - 4 } & Năm 2010 & Năm 2018 & & $-600,3$ \\
\hline 1 & Hà Nội & 114.780 & 108.378 & -6.402 & $-151,0$ \\
2 & Vĩnh Phúc & 34.624 & 33.416 & -1.208 & $-164,4$ \\
3 & Bắc Ninh & 40.151 & 38.836 & -1.315 & $+412,3$ \\
4 & Quảng Ninh & 28.531 & 31.829 & +3.298 & $-503,1$ \\
5 & Hải Dương & 66.411 & 62.386 & -4.025 & $-334,4$ \\
6 & Hải Phòng & 46.057 & 43.382 & -2.675 & $-621,3$ \\
7 & Hưng Yên & 41.927 & 36.957 & -4.970 & $-739,8$ \\
8 & Thái Bình & 84.658 & 78.740 & -5.918 & $-377,9$ \\
9 & Hà Nam & 36.428 & 33.405 & -3.023 & $-525,8$ \\
10 & Nam Định & 80.072 & 75.866 & -4.206 & $-143,0$ \\
11 & Ninh Bình & 46.307 & 45.163 & -1.144 & $\mathbf{- 3 . 9 4 8 , 6}$ \\
& Toàn vùng & $\mathbf{6 1 9 . 9 4 6}$ & $\mathbf{5 8 8 . 3 5 7}$ & $\mathbf{- 3 1 . 5 8 9}$ & \\
\hline
\end{tabular}

(Nguồn: Bộ Tài Nguyên và Môi trường 2011, 2019)

Số liệu trong bảng 2 cho thấy, tổng diện tích đất trồng lúa trong giai đoạn này giảm 31.589 ha và bình quân giảm 3.948,6 ha/năm. Có 10/11 tỉnh thành phố trong vùng có diện tích đất trồng lúa giảm, trừ tỉnh Quảng Ninh. Diện tích đất trồng lúa bị giảm nhiều nhất là thành phố Hà Nội, với bình quân giảm 800 ha/năm. Thái Bình là tỉnh có đất lúa giảm nhiều thứ 2 trong vùng với tổng diện tích giảm lên tới 5.918 ha trong 8 năm (bình quân mỗi năm giảm khoảng 740 ha). Các tỉnh Hưng Yên, Nam Định và Hải Dương có đất trồng lúa giảm trong giai đoạn 2010-2018 từ 4.0005.000 ha và chủ yếu chuyển sang để xây dựng các khu công nghiệp và khu đô thị. Các tỉnh còn lại như Vĩnh Phúc, Bắc Ninh, Hải Phòng, Hà Nam và Ninh Bình mỗi năm cũng giảm từ 140-334 ha/năm. Trong vùng chỉ có riêng tỉnh Quảng Ninh có diện tích đất lúa tăng 3.298 ha với tốc độ tăng bình quân hơn 400 ha/năm. Diện tích đất lúa ở Quảng Ninh tăng chủ yếu nhờ cải tạo diện tích đất mặn phèn ven biển.

Nguyên nhân giảm diện tích đất trồng lúa vùng ĐBSH trong giai đoạn 2010-2018 là do đất trồng lúa được chuyển đổi sang đất phi nông nghiệp, trong khi đất chưa sử dụng không còn khả 
năng khai thác để bổ sung cho quỹ đất lúa của vùng. Có thể thấy rằng, trong tương lai, bên cạnh việc mất đất trồng lúa do tác động của biến đổi khí hậu thì nhu cầu sử dụng đất phi nông nghiệp cũng sẽ tăng và tiếp tục lấy đất lúa, do đó cần có kế hoạch sử dụng đất lúa một cách hợp lý.

\subsubsection{Tình hình sủ dụng đất lúa ở vùng Đồng bằng sông Hồng giai đoạn 2010-2018}

Hiện tại, vùng ĐBSH đang gieo trồng lúa ở hai vụ chính là vụ xuân và vụ mùa. Số liệu về diện tích lúa cả năm ở các tỉnh Đồng bằng sông Hồng được trình bày tại bảng 3.

Bảng 3. Diện tích đất trồng lúa cả năm phân theo địa phưong vùng Đồng bằng sông Hồng giai doạn 2010-2018

\begin{tabular}{lrrrrrr}
\hline $\begin{array}{c}\text { Diện tích gieo } \\
\text { trồng lúa că năm }\end{array}$ & Năm 2010 & Năm 2012 & Năm 2014 & Năm 2016 & Năm 2018 & $\begin{array}{c}\text { So sánh } \\
\mathbf{2 0 1 8} / \mathbf{2 0 1 0}\end{array}$ \\
\hline Toàn vùng & $1.150,1$ & $1.138,7$ & $1.122,7$ & $1.094,4$ & $1.040,7$ & $-109,4$ \\
Hà Nội & 204,7 & 205,4 & 202,8 & 197,1 & 179,5 & $-25,2$ \\
Vĩnh Phúc & 59,3 & 59,4 & 58,6 & 58,4 & 56,6 & $-2,7$ \\
Bắc Ninh & 74,3 & 72,6 & 72,7 & 70,8 & 66,4 & $-7,9$ \\
Quảng Ninh & 44,7 & 43,6 & 43,1 & 42,3 & 41 & $-3,7$ \\
Hải Dương & 127,5 & 126,4 & 125 & 120,3 & 116,4 & $-11,1$ \\
Hải Phòng & 80,9 & 79,2 & 77,1 & 74 & 69,4 & $-11,5$ \\
Hưng Yên & 81,9 & 81,8 & 78,9 & 74,1 & 66,4 & $-15,5$ \\
Thái Bình & 166,4 & 162,8 & 161,8 & 160,1 & 157,1 & $-9,3$ \\
Hà Nam & 70,3 & 69 & 67,4 & 65,6 & 63,2 & $-7,1$ \\
Nam Định & 159 & 157,3 & 154,9 & 153 & 149,1 & $-9,9$ \\
Ninh Bình & 81,1 & 81,2 & 80,4 & 78,7 & 75,6 & $-5,5$ \\
\hline
\end{tabular}

(Nguồn: Tổng cuc thống kê, 2019)

Số liệu bảng 3 cho thấy, cùng với giảm diện tích đất lúa thì diện tích gieo trồng lúa cả năm ở vùng ĐBSH cũng giảm tương ứng. Trong 8 năm (từ 2010-2018), diện tích gieo trồng lúa cả năm của ĐBSH đã giảm 109,400 ha với tốc độ bình quân 13,675 ha/năm. Thành phố Hà Nội có tốc độ giảm diện tích lúa lớn nhất với tốc độ bình quân 3,150 ha/năm. Diện tích lúa của Hà Nội giảm mạnh do ảnh hưởng của đô thị hóa, đất lúa bị chuyển sang các mục đích phi nông nghiệp khác.

Trong giai đoạn 2010-2018, hệ số sử dụng đất lúa cũng thay đổi từ 1,85 lần năm 2010 đến 1,77 lần năm 2018. Hệ số sử dụng đất lúa năm 2018 của các tỉnh vùng ĐBSH được thể hiện trong hình 2 [2].

Hình 2 cho thấy, chỉ có hai tỉnh là Thái Bình và Nam Định có hệ số sử dụng đất lúa gần bằng 2 có nghĩa là phần lớn diện tích đất lúa là đất trồng 2 vụ lúa/năm. Quảng Ninh là tỉnh có hệ số sử dụng đất lúa thấp nhất $(1,29)$ do diện tích lúa trồng cấy chủ yếu vào vụ mùa, vụ xuân chỉ có 16,300 ha lúa, chiếm $39,7 \%$ diện tích lúa gieo trồng cả năm. Vụ xuân một số diện tích đất lúa phải trồng cây khác do khó khăn về nước tưới. Hệ số sử dụng đất lúa của toàn vùng là 1,77 ; trong khi hệ số này của toàn quốc là 1,84 .

Theo dõi biến động về năng suất lúa toàn vùng trong giai đoạn 2010-2018 (hình 3) [2] có thể thấy, trong giai đoạn 2012-2014 năng suất toàn vùng cao trung bình khoảng 60,3 tạ/ha/vụ. Từ năm 2014 đến năm 2018 , năng suất lúa toàn vùng giảm dần. Đến năm 2018 năng suất toàn vùng còn 56,8 tạ/ha. Sở dĩ có sự giảm năng suất là do giai đoạn 2014 đến nay ở nhiều tỉnh đã dần thay thế các giống lúa lai có năng suất cao nhưng chất lượng gạo không ngon bằng các giống lúa thuần, lúa đặc sản có chất lượng cao để đáp ứng yêu cầu ngày càng cao của thị trường. Mặc dù năng suất thấp hơn nhưng những giống lúa này cho giá trị sản xuất cao hơn và dễ tiêu thụ hơn.

Năng suất lúa bình quân ở các tỉnh vùng ĐBSH năm 2018 được thể hiện trong hình 4 [2].

Quảng Ninh là tỉnh có năng suất lúa bình quân thấp nhất toàn vùng và chỉ đạt 47,1 tạ̣/ha/vụ. Hải Phòng và Bắc Ninh, Hưng Yên và Thái Bình là những tỉnh có năng suất lúa cao nhất vùng, đạt khoảng 60 tạ/ha/vụ. Như vậy, năng suất lúa của ĐBSH vẫn cao hơn năng suất lúa bình quân của cả nước khoảng 2 tạ/ha/vụ và đứng thứ hai trong các vùng sinh thái cả nước chỉ sau ĐBSCL. 


\subsubsection{Hiệu quả kinh tế của các loại hình sủ dụng đất lúa vùng Đồng bằng sông Hồng}

Hiệu quả kinh tế của 5 loại sử dụng đất được thể hiện trong bảng 4 .

Bảng 4. Hiệu quả kinh tế của các loại sủ̉ dụng đất lúa vùng Đồng bằng sông Hồng năm 2018

\begin{tabular}{|c|c|c|c|c|c|c|c|}
\hline \multirow{2}{*}{ TT } & \multirow{2}{*}{ Loại sử dụng đất } & GTSX & CPTG & TNHH & \multirow{2}{*}{$\begin{array}{c}\text { Công lao } \\
\text { động }\end{array}$} & \multirow{2}{*}{$\begin{array}{c}\text { Giá trị } \\
\text { ngày công }\end{array}$} & \multirow{2}{*}{$\begin{array}{c}\text { HQĐV, } \\
\text { (lần) }\end{array}$} \\
\hline & & \multicolumn{3}{|c|}{ triệu đồng/ ha/năm } & & & \\
\hline 1 & 2 vụ lúa & 87,81 & 31,32 & 56,49 & 430 & 131 & 1,80 \\
\hline 2 & Lúa xuân - lúa mùa + ngô/ khoai & 125,15 & 42,18 & 82,97 & 521 & 159 & 1,97 \\
\hline 3 & Lúa xuân - lúa mùa + rau vụ đông & 231,00 & 87,50 & 143,50 & 750 & 191 & 1,64 \\
\hline 4 & 1 Lúa - 2 vụ rau màu & 168,06 & 40,98 & 127,08 & 694 & 183 & 3,10 \\
\hline 5 & Lúa xuân - cá & 292,95 & 88,79 & 204,16 & 400 & 510 & 2,30 \\
\hline
\end{tabular}

(Nguồn: Kết quả điều tra nông hộ)

Kết quả nghiên cứu tại bảng 4 cho thấy, trong các loại sử dụng đất trồng lúa thì LUT 5 có hiệu quả kinh tế cao nhất với thu nhập hỗn hợp là 204,16 triệu đồng/ha/năm và hiệu quả đồng vốn là 2,3 lần. Mô hình này đòi hỏi rất ít công lao động, giá trị ngày công cao, cá ăn lúa chét (lúa tái sinh) trên đồng nên đỡ được rất nhiều chi phí thức ăn. Tuy nhiên, loại sử dụng đất này chỉ áp dụng được trên những vùng đất trũng, có thể cấp, thoát nước thuận tiện và phải cải tạo khoảng $20 \%$ diện tích ruộng thành các mương cho cá. LUT 3 và 4 cũng là những LUT mang lại hiệu quả kinh tế cao với thu nhập hỗn hợp đạt từ 127-143,5 triệu đồng/ha/năm và hiệu quả đồng vốn đạt 1,64 đến 3,1 lần. Tuy nhiên, đây là những LUT đòi hỏi nhiều công lao động nên không phù hợp với những vùng ven thành phố hoặc có ngành nghề phụ - nơi người dân có thể có thu nhập cao hơn từ các nghề khác. LUT 1 và 2 tuy không mang lại hiệu quả kinh tế cao nhưng lợi thế là chi phí thấp, kỹ thuật đơn giản, đòi hỏi rất ít công lao động nên được người dân ngoại thành và những khu vực có mức độ công nghiệp hóa mạnh ưa thích lựa chọn.

\section{Kết luận}

Vùng ĐBSH có diện tích 588.357 nghìn ha đất trồng lúa, chiếm 15,04\% diện tích đất lúa cả nước (2018). Giai đoạn từ năm 2010 đến năm 2018, diện tích đất trồng lúa đã giảm 31.589 ha với tốc độ giảm bình quân 3.948,6 ha/năm. Năm 2018, vùng ĐBSH có diện tích gieo trồng lúa là 1.040.700 ha, năng suất lúa bình quân đạt 56,8 tạ/ha, cao hơn năng suất lúa bình quân của cả nước khoảng 2 tạ/ha/vụ và đứng thứ hai trong các vùng sinh thái cả nước (chỉ sau có ĐBSCL). So với toàn vùng, vụ xuân có diện tích gieo trồng lúa ít hơn vụ mùa nhưng năng suất lúa và sản lượng lúa cao hơn vụ mùa.

Hầu hết các tỉnh (10/11 tỉnh) đều giảm diện tích đất lúa (trừ tỉnh Quảng Ninh), bình quân giảm từ $143-800$ ha/năm, trong đó Hà Nội giảm nhiều nhất. Mức độ thâm canh lúa cao, hệ số sử dụng đất lúa thay đổi từ 1,85 lần (2010) đến 1,77 lần (2018). Năng suất lúa toàn vùng giai đoạn 2010-2012 tăng và từ 2012-2018 có dấu hiệu giảm.

Sản xuất lúa đã đem lại hiệu quả kinh tế từ trung bình đến khá cho người dân. Trong đó, tổng thu nhập cao nhất là loại sử dụng đất lúa - cá (LUT5) với thu nhập hỗn hợp đạt được 204,16 triệu đồng/ha/năm và hiệu quả đồng vốn đạt 2,3 lần. Hiệu quả thấp nhất là LUT 2 vụ lúa với thu nhập hỗn hợp chỉ đạt 56,49 triệu đồng/ha/ năm.

\section{Lời cám ơn}

Tác giả xin gửi lời cảm ơn đến Bộ Khoa học và Công Nghệ và Chủ nhiệm đề tài độc lập cấp quốc gia: "Nghiên cứu, đánh giá tác động của biến đổi khí hậu đến tài nguyên đất vùng Đồng bằng sông Hồng và đề xuất các giải pháp chủ động ứng phó" đã cấp kinh phí để thực hiện nghiên cứu này. 


\section{TÀI LIẸU THAM KHẢO/ REFERENCES}

[1] T. H. X. Le, "Rice market report 2020," 2020. [Online]. Available: https://cdn.vietnambiz.vn/171464876016439296/2021/1/20/bao-cao-thi-truong-gao-nam-202016111472504561619634030.pdf. [Accessed August 15, 2021].

[2] Bureau of Statistics, Statistical Yearbook 2010, 2018. Statistical Publishing House, 2019.

[3] General Statistics Office, "Statistical analysis and forecast reports in 2019," 2020. [Online]. Available: https://www.gso.gov.vn/wp-content/uploads/2020/11/Ky-yeu-2019.pdf, Ha Noi, pp. 20. [Accessed August 10, 2021].

[4] T. T. Nguyen, C. D. Le, and Q. T. Le, "Orientation of agricultural land use adaptating for climate change in the Mekong Delta," (In Vietnamese), Journal of Soil Science, no. 58/2020, pp. 5-10, 2020.

[5] T. H. D. Nguyen, K. D. Phan, V. V. Tran, and Q. M. Vo, "Changes of major Mekong Delta coastal soil types under different climate change scenarios," (In Vietnamese), Journal of Soil Science, no. 49/2016, pp. 17-21, 2016.

[6] B. N. Tran, "Assessments of CMIP3 Climate Models and Projected Climate Changes of Precipitation and Temperature for Vietnam and the Southeast Asia," VNU Journal of Science: Earth and Environmental Sciences, vol. 36, no 3, pp. 37-45, 2020, doi: 10.25073/2588-1094/vnuees.4585 no 3.

[7] T. A. Luu, M. H. Pham, T. H. H. Vu, T. T. Kieu, N. T. Nguyen, and T. B. Nguyen, “Assessment of the impacts of urbanization on agricultural land in the Red River Delta using multi-temporal remote sensing data and GIS," Journal of Geodesy and Cartography, no. 40, pp. 42-49, 2019.

[8] World Bank (WB), Vietnam Development Report 2016, Vietnam's agricultural transformation: increasing value, reducing input. Hong Duc Publishing House, Hanoi, p. 13, 2016.

[9] Institute of Agricultural Planning and Design, Planning for crop conversion on rice land in the period 2014 - 2020, 2014.

[10] Ministry of Natural Resources and Environment, Decision No. 2908/QD-BTNMT, November 13, 2019. Decision approving and announcing the results of the 2018 Land System by the Minister of Natural Resources and Environment, 2019. 